\title{
Long-term response planting method on wheat under conservation agriculture
}

\author{
María Isabel Escobosa-García ${ }^{1}$; Luis Fernando Escoboza-García ${ }^{2}$; Roberto Soto-Ortiz ${ }^{1}$; \\ Carlos Orozco-Riezgo ${ }^{1}$; Jesús del Rosario Ruelas-Islas ${ }^{3}$; Francisco Higinio Ruiz-Espinoza ${ }^{4}$; \\ Fidel Núñez-Ramírez ${ }^{1 *}$ \\ 1 Universidad Autónoma de Baja California, Instituto de Ciencias Agrícolas, Mexicali, Baja California, \\ México. \\ 2 Consultor Certificado en Agricultura de Conservación. Agrovisión, Mexicali, Baja California, México. \\ 3 Universidad Autónoma de Sinaloa, Juan José Ríos, Ahome, Sinaloa, México. C.P 81110. \\ 4 Universidad Autónoma de Baja California Sur, La Paz, Baja California Sur, México. C.P. 23000. \\ * Correspondence: fidel.nunez@uabc.edu.mx
}

Gitation: Escobosa-García, M. I., Escoboza-García, L. F., Soto-Ortiz, R., Orozco-Riezgo, C., Ruelas-Islas, J. del R., Ruiz-Espinoza, F. H., Núñez-Ramírez, F. (2021). Long-term response planting method on wheat under conservation agriculture. Agro Productividad. https://doi.org/10.32854/ agrop.v14il1.2166

Editor in Chief: Dr. Jorge Cadena Iñiguez

Received: April 23, 2021. Accepted: November 4, 2021. Published on-line: November 30, 2021 .

This work is licensed under a Creative Commons Attribution-NonCommercial 4.0 International license.

\begin{abstract}
Objective: To compare different planting systems: narrow beds, wide beds, and flat soil, on the growth and yield of wheat grown under conservation system.

Design/methodology/approach: Wheat crop was grown during five seasons. Treatments were established on a complete block design with three replicates: wide beds $(100 \mathrm{~cm})$, narrow beds $(80 \mathrm{~cm})$ and planting on flat soil. Response variables were dry weight of 50 stems, weight of 1000 grains, number of spikes $\left(\mathrm{m}^{2}\right)$, harvest index and yield. The relationship between yield and chill hours, and degree-days were identified.

Results: Flat soil reached the highest dry weight of 50 stems, whereas narrow beds had the maximum number of spikes per $\mathrm{m}^{2}$. Yield was equal between flat soil and narrow beds. No differences were found in the harvest index between the evaluated treatments. When comparing results between years, dry weight of 50 stems increased and the harvest index decreased, negatively affecting the yield. A negative association was found between chill hours and yield.

Study limitations/implications: The use of wide beds reduces wheat crop yield, and the use are not recommended.

Findings/conclusions: Yield was the same with narrow beds and flat soil planting. The yield reduction was mainly associated with of reduction in chill hours occurring in each season.
\end{abstract}

Keywords: climate; environment; grain yield; plant density; topological arrangement.

\section{INTRODUCTION}

The Mexicali valley is in the state of Baja California in Northwest Mexico. It has an approximate area of 105,000 irrigated hectares, of which 98,000 hectares are crops of wheat (Triticum aestivum L.) cultivated during the months of November through May (SIAP, 2014). Traditionally, most growers employ the flat planting system for wheat under conventional tilling practices. The system includes the subsoiling, disking and mould board plough. Besides, straw is usually burned after harvest, which substantially affects microbial activity in soils (Wuest et al., 2005). 
Wheat grain yield attained by the use of this technology has reached an average of $6.8 \mathrm{Mg} \mathrm{ha}^{-1}$ (Salinas-Zavala, Salvador, Lluch-Cota \& Fogel, 2006). However, it can be enhanced by increasing the number of irrigations (Kakar \& Iqbal, 2015) and employing different management practices such as bed planting system. Additionally, profitability of this crop can be increased by employing conservation tillage system (minimum tillage, crop rotation, straw incorporation) (Govaerts et al., 2009).

In conservation agriculture system, the soil is ploughed as in conventional system during the first year. After that time, soil is not disturbed; crop rotation and all crop remains are incorporated over the surface. The planting method consists of raised beds $(80-100 \mathrm{~cm})$ with two or three rows of plants on the top of the bed (Limon-Ortega, Sayre, Drijber, \& Francis, 2002).

With conservation agriculture, growers can achieve fuel costs savings up to $30 \%$ (Lal, 2004) increase nitrogen concentration, organic matter content in soil (Zuber et al., 2015) and keep stable yield (Kassam et al., 2009). Fahonga, Xuqinga \& Sayre (2004) mention that bed planting system provides advantages in water saving $(30 \%)$ when compared to flat soil planting. They also indicate that soil crusting problems are reduced because the seed bed surface improves physical structure. Besides, N use efficiency is increased up to $30 \%$, microclimate favors crop stand, reduces lodging and presence of plant diseases. Weed management and fertilization timing practices are substantially improved (Govaerts, Sayre, \& Deckers, 2005).

The use of bed planting in wheat crops has been recommended for more than a decade in the Yaqui valley (state of Sonora) as well as in high valleys of central Mexico (Govaerts $e t$ $a l ., 2005)$. Nevertheless, the use of this technology in Mexicali valley is under research due to different cropping systems (type of soil, irrigation water quality and environment) which are contrasting to the places above mentioned. In that sense, a study was conducted during five years in order to compare different bed planting systems (flat soil, wide beds $(100 \mathrm{~cm})$ and narrow beds $(80 \mathrm{~cm})$ on the growth and yield of wheat under conservation system.

\section{MATERIALS AND METHODS}

The research was carried out at the experimental platform for conservation agriculture located at the Agricultural Science Institute at University of Baja California (32 24 ' 12.34 "' $\left.\mathrm{N}, 115^{\circ} 11^{\prime} 47.37^{\prime \prime} \mathrm{W}\right)$. The weather of this region is arid with periods of rain in winter (BW [h'] hs [x'] [e']; (INIFAP, 2010), summer temperatures up to $50{ }^{\circ} \mathrm{C}$ and winter temperatures of $-7^{\circ} \mathrm{C}$, the mean annual temperature is $22.3^{\circ} \mathrm{C}$ and the mean annual precipitation is $58 \mathrm{~mm}$.

The soil from the experimental site is classified as clayed (vertisol), bulk density of $1.16 \mathrm{~g} \mathrm{~cm} 3$, electrical conductivity (EG) of $4.44 \mathrm{dS} \mathrm{m}^{-1}, \mathrm{pH} 7.83,33 \mathrm{ppm}$ of phosphorus content, $395 \mathrm{ppm}$ of potassium, $5236 \mathrm{ppm}$ of calcium, $1255 \mathrm{ppm}$ of magnesium and 672 ppm of sodium respectively. Irrigation water flowed from Colorado River, the $\mathrm{pH}$ was of 8.18, EC of $1.28 \mathrm{dS} \mathrm{m}^{-1}$ and 122.0, 61.4, 154.8, 177.1, 243.5, 421.8 $\mathrm{mg} \mathrm{L}^{-1}$ of calcium, magnesium, sodium, bicarbonates, chlorides and sulfates approximately.

The experiment was established in a big area of land under conservation agriculture system. The tillage techniques were those recommended by CIMMYT (2009). The first year of the study (2011-2012), land was ploughed using conventional system (subsoiling, 
disking and leveling). Subsequently, all treatments were established on a complete block design with three replicates. Plots had a length of $140 \mathrm{~m}$ and $12 \mathrm{~m}$ wide. Treatments were: A) wide beds (furrows at $100 \mathrm{~cm}$ ), wheat was planted in twin line (two rows $27 \mathrm{~cm}$ apart) (Figure 1) and seed density of $80 \mathrm{~kg} \mathrm{ha}^{-1}$; B) narrow beds (furrows at $80 \mathrm{~cm}$ ) (two rows 27 cm apart) and the same seeding rate; C) flat soil with a seed density of $160 \mathrm{~kg} \mathrm{ha}^{-1}$.

Planting and harvest dates were as follow: A) December $6^{\text {th }}, 2011$, and June $15^{\text {th }}$ 2012 first growing season; B) December $15^{\text {th }} 2012$ and June $15^{\text {th }} 2013$ second growing season, G) November $15^{\text {th }} 2013$ and June $7^{\text {th }} 2014$ third growing season, D) November $22^{\text {nd }} 2014$ and June $4^{\text {th }} 2015$ fourth growing season, E) November 252015 and June $15^{\text {th }}$ 2016 the fifth growing season. The variety planted was Rio Colorado during all growing seasons.

Planting on wide and narrow beds was realized with a multifunctional seed drill (manufactured by Industrias Vázquez S.A de G.V); flat soil planting system was realized with a special seed drill (Dobladense 290-17 ${ }^{\circledR}$ ). Fertilization rates were of $276 \mathrm{~kg}$ of nitrogen using urea $\left[\mathrm{CO}\left(\mathrm{NH}_{2}\right)_{2}\right]$ and $78 \mathrm{~kg}$ of phosphorus using monoammonium phosphate (MAP11-52-00). Total $\mathrm{P}$ and 25\% of $\mathrm{N}$ were pre-plant applied, 33\% of $\mathrm{N}$ applied in the first postplant irrigation, $25 \%$ in the second post-plant irrigation while the last $17 \%$ in the third post-plant irrigation. Pest and weed management were realized following the guideline provided by Hernández, Guzmán \& Valenzuela (2010).

Response variables were dry weight of 50 stems (season 2013-14; 2014-15 and 201516), number of spikes $\left(\mathrm{m}^{2}\right)$ (season 2014-15 and 2015-16), weight of 1000 grains (season 2013-14, 2014-15 and 2015-16), harvest index (season 2011-12, 2013-14 and 2015-16) and yield (from 2011 through 2016). It was also identified the ratio of annual yield relative to chill hours and degree-days from planting to February (year). The reason for considering February is because heading usually occurs during this time (Verhulst, Kienle, Sayre, Deckers, \& Raes, 2014).

To determine $\mathrm{DW}_{50 \text { stems, }}$ plant material was taken at harvest, placed on a forced air-dry oven $\left(65^{\circ} \mathrm{C}\right)$ until constant dry weight. Harvest index $(\mathrm{HI})$ was obtained by the ratio of dry weight of 50 stems relative to grain weight. Number of spikes were also counted $\left(\mathrm{m}^{2}\right)$. Yield was estimated by harvesting plants on $2 \mathrm{~m}^{2}$ segment. Climatic conditions were monitored

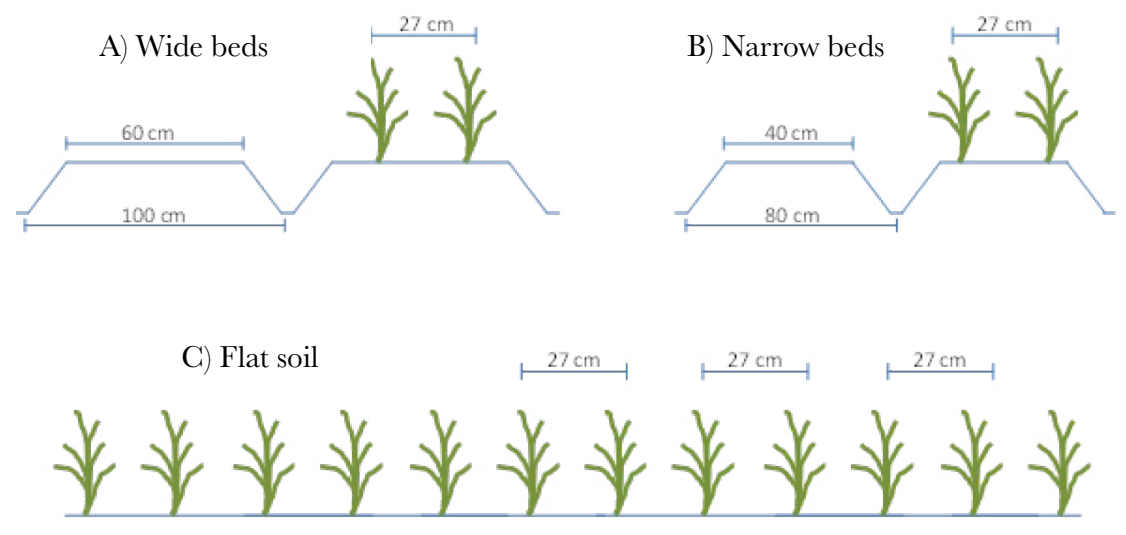

Figure 1. Different planting systems on wheat production. 
with a meteorological station located at $840 \mathrm{~m}$ from the experimental site during all years of the study. The daily chill hours and degree-days were obtained from a meteorological network station (SIMABC, http://www.simarbc.gob.mx/).

All data obtained was analyzed separately due to different variables measured. Analysis of variance was conducted between treatments, treating years as the fixed factor, ANOVA between years considering treatments as the fixed factor, mean differences between treatments or years, were separated using Tukey's least significance difference (LSD) at $\mathrm{P} \leq 0.05$. Additionally, regression models were fitted between accumulated chill hours and degree-days with respect to grain yield.

\section{RESULTS AND DISCUSSION}

Table 1 shows the maximum and minimum temperatures during the time of the experiment. It also shows the average monthly maximum and minimum temperatures from 1961 through 2003. It is shown that temperatures obtained during the study were very similar to those recorded from 1962 to 2003 . Maximum temperatures registered from January through may increase from 4.9 a $8.7^{\circ} \mathrm{C}$ as compared to those registered in the period of 1961 to 2003.

Table 2 shows the monthly Degree-days (DD) and chill hours $(\mathrm{CH})$ accumulation during the study. As the time passed during the period of the experiment, the months from February through March exhibited a reduction in the $\mathrm{CH}$ accumulation and increased the DD accumulation.

According to analysis of variance, there were significant differences in variables of dry weight 50 stems, spikes $\left(\mathrm{m}^{2}\right)$ and yield of crop by the effect of planting methods (Table 3 ). The greatest weight of 50 stems was registered on flat soil planting. The greatest number of spikes was recorded on narrow bed planting. Lastly, the lowest yield was attained on wide bed planting. However, there were no significant differences on weight of 1000 grains and $\mathrm{HI}$.

Significant differences were found in variables of $\mathrm{DW}_{50 \text { stems, }} \mathrm{DW}_{1000 \text { grains }}, \mathrm{HI}$ and yield of crop during the years of the study (Table 4). The highest value of $\mathrm{DW}_{50}$ stems was attained during the season 2015-2016. The yield and HI decreased as the time passed. In addition, $\mathrm{DW}_{1000 \text { grains }}$ decreased on the season 2014-15 as compared to seasons 2013-14 and 2015-16. Furthermore, the number of spikes $\left(\mathrm{m}^{2}\right)$ was not affected during the time of the experiment.

Table 4 shows the analysis of variance and mean comparison for the variables of $\mathrm{DW}_{50 \text { stems, }}$, spikes $\mathrm{m}^{2}, \mathrm{DW}_{1000 \text { grains }}, \mathrm{HI}$ and yield in five years of study. It was observed that as time passed, $\mathrm{DW}_{50}$ stems significantly increased $(\mathrm{P}>0.01)$ to double the weight attained during the season 2013-14 as compared to season 2015-16. However, there were no significant differences on the number of spikes $\left(\mathrm{m}^{2}\right)$ during the years of study

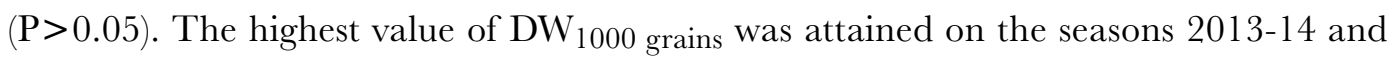
2015-16 as compared to season 2014-15. HI increased on seasons 2011-12 and 2013-14, but it decreased on season 2015-16. The same tendency was observed when analyzing yield between years. Yield potential significantly decreased as time passed. 


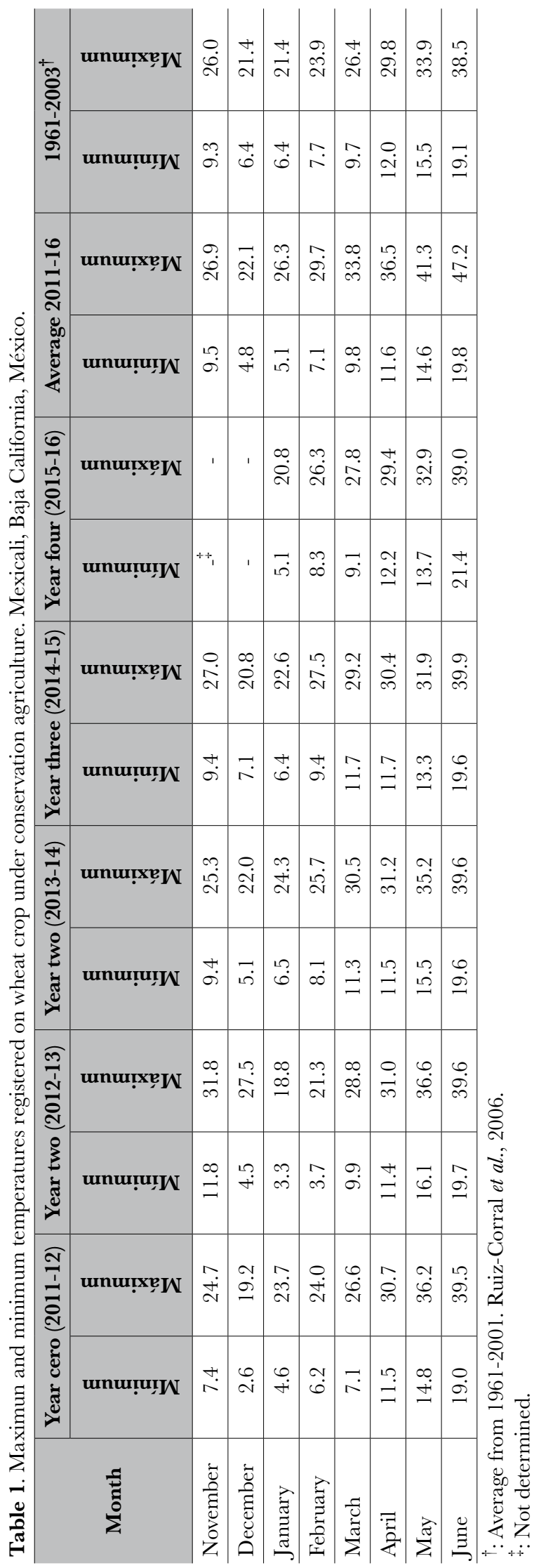


Table 2. Degree-days (DD) and chill hours $(\mathrm{CH})$ accumulation registered on wheat crop under conservation agriculture. Mexicali, Baja California, México ${ }^{\dagger}$.

\begin{tabular}{|c|c|c|c|c|c|c|c|c|c|c|}
\hline \multirow{2}{*}{ Month/year } & \multicolumn{2}{|c|}{ 2011-12 } & \multicolumn{2}{|c|}{ 2012-13 } & \multicolumn{2}{|c|}{ 2013-14 } & \multicolumn{2}{|c|}{ 2014-15 } & \multicolumn{2}{|c|}{ 2015-16 } \\
\hline & GH & DD & $\mathbf{C H}$ & DD & CH & DD & $\mathbf{C H}$ & DD & CH & DD \\
\hline November & 139 & 254 & 0 & 113 & 70 & 292 & 76 & 337 & 267 & 0 \\
\hline Dicember & 375 & 105 & 0 & 0 & 306 & 154 & 211 & 180 & 235 & 59 \\
\hline January & 269 & 206 & 0 & 0 & 195 & 242 & 188 & 211 & 266 & 150 \\
\hline February & 203 & 199 & 195 & 110 & 110 & 269 & 67 & 322 & 107 & 303 \\
\hline March & 139 & 309 & 61 & 392 & 23 & 384 & 36 & 441 & 40 & 365 \\
\hline April & 25 & 446 & 12 & 455 & 12 & 456 & 8 & 442 & 9 & 443 \\
\hline May & 0 & 626 & 0 & 631 & 0 & 602 & 7 & 529 & 0 & 549 \\
\hline June & 0 & 731 & 0 & 747 & 0 & 716 & 0 & 743 & 0 & 767 \\
\hline TOTAL & 1150 & 2876 & 268 & 2448 & 716 & 3115 & 593 & 3205 & 924 & 2636 \\
\hline
\end{tabular}

†: SIMARBC. 2016. http://www.simarbc.gob.mx/

Table 3. Effect of planting method on dry weight of 50 stems, spikes $\left(\mathrm{m}^{2}\right)$, weight of 1000 grains, HI and yield of wheat crop (2011-12 through 2015-16).

\begin{tabular}{l|c|c|c|c|c}
\hline $\begin{array}{c}\text { Planting } \\
\text { method }\end{array}$ & DW & Spikes $\mathbf{~ s t e m s ~}^{\mathbf{2}}$ & $\mathbf{D W}_{\mathbf{1 0 0 0} \text { grains }}(\mathbf{g})$ & HI & Yield $\left(\mathbf{t} \mathbf{~ h a}^{-\mathbf{1}}\right)$ \\
\hline Flat soil & $193.54 \mathrm{a}$ & $270 \mathrm{~b}$ & 77.61 & 0.393 & $6.45 \mathrm{a}$ \\
\hline Narrow beds & $158.83 \mathrm{~b}$ & $370 \mathrm{a}$ & 73.73 & 0.385 & $6.40 \mathrm{a}$ \\
\hline Wide beds & $176.21 \mathrm{~b}$ & $255 \mathrm{~b}$ & 76.66 & 0.398 & $5.23 \mathrm{~b}$ \\
\hline Significance & $* *$ & $*$ & NS & NS & $*$ \\
\hline
\end{tabular}

NS: non significant; *, **. Significant at $\mathrm{P}<0.05, \mathrm{P}<0.01$, respectively.

Table 4. Mean comparison of yield components on wheat in five growing seasons (2011 to 2016).

\begin{tabular}{|c|c|c|c|c|c|}
\hline Year & $\mathrm{DW}_{50 \text { stems }}(\mathrm{g})$ & spikes $\mathbf{m}^{2}$ & $\mathrm{DW}_{1000}$ grains $(\mathrm{g})$ & HI & Yield $\left(\mathrm{t} \mathrm{ha}^{-1}\right)$ \\
\hline $2011-12$ & - & - & - & $0.433 \mathrm{a}$ & $6.87 \mathrm{a}$ \\
\hline 2012-13 & - & - & - & - & $6.98 \mathrm{a}$ \\
\hline 2013-14 & $117.07 \mathrm{c}$ & - & $83.22 \mathrm{a}$ & $0.414 \mathrm{a}$ & $6.03 \mathrm{a}$ \\
\hline 2014-15 & $160.93 \mathrm{~b}$ & 298 & $63.12 \mathrm{~b}$ & - & $5.33 \mathrm{ab}$ \\
\hline $2015-16$ & $250.58 \mathrm{a}$ & 309 & $81.66 \mathrm{a}$ & $0.327 \mathrm{~b}$ & $4.94 \mathrm{~b}$ \\
\hline Significance & $* *$ & NS & $*$ & $*$ & $*$ \\
\hline
\end{tabular}

NS: non significant; *,

**; ***. Significant at $\mathrm{P}<0.05, \mathrm{P}<0.01$, y $\mathrm{P}<0.001$ respectively.

The regression model showed that yield increased as the number of chill hours units also increased $\left(\mathrm{R}^{2}=0.4355, \mathrm{P}<0.007\right.$; Figure 2). The regression equation indicated that yield increased $1.35 \mathrm{t} \mathrm{ha}^{-1}$ for every 100 for every 100 chill hours accumulated to February. A different behavior was observed with respect to degree-days accumulation and yield (Figure 3). The regression equation showed that yield decreased $0.94 \mathrm{t} \mathrm{ha}^{-1}$ for every 100 degree-days accumulated to February $\left(\mathrm{R}^{2}=0.4487\right.$; $<$ 0.006). 


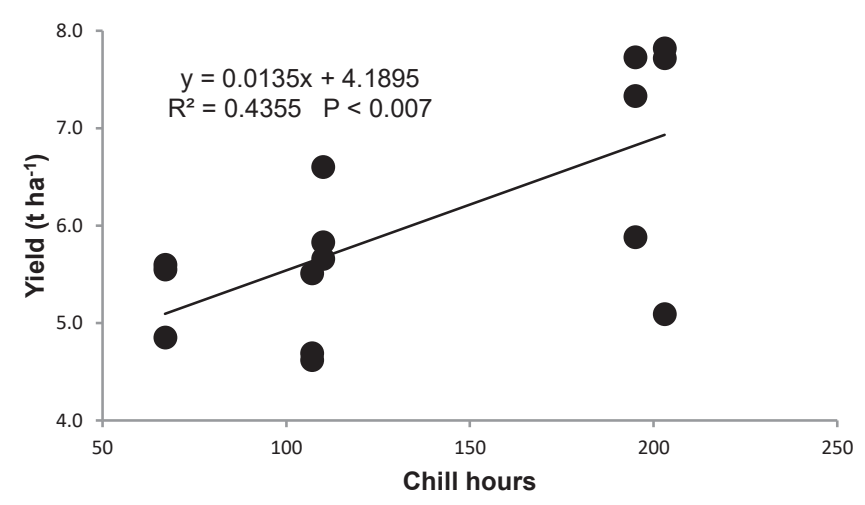

Figure 2. Relationship between chill hours accumulation and yield of wheat in five years.

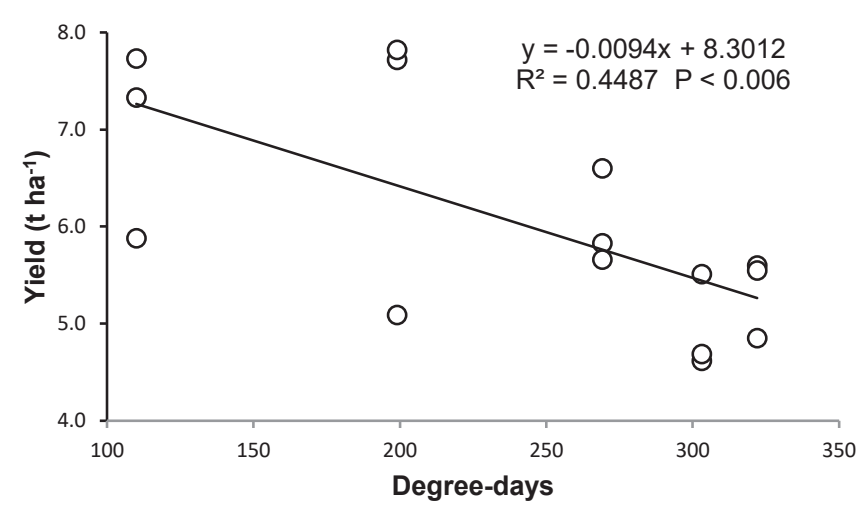

Figure 3. Relationship between degree-days accumulation and yield of wheat in five years.

It is estimated that conservation agriculture system worldwide is growing at a rate of 5.3 million of hectares per year (Kassam, Friedrich, Shaxson \& Pretty, 2009). Recently, number of studies show the benefits of this production system. This practice involves the evaluation of climatic and edaphic conditions for each region and the crop response to them (Verhulst, Kienle, Sayre, Deckers, Limon-Ortega, Tijerina-Chavez \& Govaerts, 2011). It is observed that yield of wheat under raised bed planting system has not exceed the yield obtained under flat planting system in regions with arid climate and soil saline conditions (Saifuzzaman et al., 2011). However, when there is an increase in yield, it has been associated to improvement in soil conditions (incorporation of crop remains) (LimónOrtega et al., 2011).

This study evaluated three planting systems on the growth and yield of wheat under environmental conditions of Mexicali Baja California. The flat planting and the narrow bed planting system provided the same yield; while the yield under wide bed planting system was reduced. It is possible that decrease in yield on this system was due to spacing between them. Fischer et al. (2019) have also documented this response. Nevertheless, they stated that yield could fluctuate between years because of low temperatures at the time of planting and crop emergence. They also mentioned that wheat late plantings (past January) lead to better yields. 
It was identified a significant relationship between yield drop and increase of temperatures on February $(\mathrm{P}<0.006)$. According to Verhulst et al. $(2011)$, it is just the period for completing the stage of heading and beginning of stem elongation. This process could have modified the pattern of dry matter partitioning to stems, leading to a decrease in harvest index (Banerjee and Krishnan, 2015). The hypothesis is contrasting because of the increase in chill hours during the same month (February). Nuttall et al. (2018) indicated that heat waves in period before flowering affected the yield. On the other hand, Calderini et al. (1999) exhibited that lowering yields are associated to temperature drop between stages of growth.

\section{CONGLUSIONS}

Stem dry weight, number of spikes and yield of crop were affected by the planting system. The lowest yield was attained on the wide bed planting system. Meanwhile, grain weight and harvest index were not affected by the planting method. Furthermore, the weight of stems was increased but the harvest index was reduced by the effect of year. There was also an association between the yield and cold units accumulated during the month of February. Overall, the narrow bed planting system can be a potential management practice in maintaining yield potential of wheat.

\section{REFERENGES}

Banerjee, V. \& Krishnan P. (2015). Effect of high temperature stress on biomass partitioning in wheat (Triticum aestivum L.) at different growth stages. Journal of Agricultural Physics, 15(2) 122-126. Doi: 10.13140/ RG.2.2.26670.00320

Calderini, D. F., Abeledo, L. G., Savin, R. \& Slafer, G. A. (1999). Final grain weight in wheat as affected by short periods of high temperature during pre- and post anthesis under field conditions. Aust. J. Plant Physiol. 26: 453-458. Doi: 10.1071/PP99015

Fahong, W., Xuqing, W. \& Sayre, K. (2004). Comparison of conventional, flood irrigated, flat planting with furrow irrigated, raised bed planting for winter wheat in China. Field Crops Research 87(1): 35-42. Doi: 10.1016/j.fcr.2003.09.003

Fischer, R. A., Moreno Ramos, O. H., Ortíz Monasterio, I. \& Sayre, K. D. (2019). Yield response to plant density, row spacing and raising beds in low latitude spring wheat whit ample soil resources: An update. Fields Crops Research 232: 95-105. Doi: 10.1016/j.fcr.2018.12.011

Govaerts, B., Sayre, K. D., \& Deckers, J. (2005). Stable high yields with zero tillage and permanent bed planting? Field Crops Research, 94(1), 33-42. Doi: 10.1016/j.fcr.2004.11.003

Govaerts, B., Sayre, K. D., Goudeseune, B., De Corte, P., Lichter, K., Dendooven, L., \& Deckers, J. (2009). Conservation agriculture as a sustainable option for the central Mexican highlands. Soil and Tillage Research, 103(2), 222-230. Doi: 10.1016/j.still.2008.05.018

Hernández Vázquez, B., Guzmán Ruiz, S de C. y Valenzuela Palafox, J. A. (2010). Guía para producir trigo en los valles de Mexicali, B. C. y San Luis Rio Colorado, Son. Instituto Nacional de Investigaciones Forestales, Agrícolas y Pecuarias Centro de Investigación Regional del Noroeste Campo Experimental Valle de Mexicali Mexicali, B. C., Noviembre de 2010. Folleto para Productores, 28 pp. http://www.oeidrus-bc. gob.mx/sispro/trigobc/Produccion/Paquetes/Trigo2010.pdf

Kakar, K. M., \& Iqbal, A. (2015). Effect of irrigation levels and bed-system of planting on seed fill duration, seed growth rate, yield and yield components of spring wheat (Triticum aestivum) under semiarid condition. Pure Appl. Biol., 4(4), 511-521. Doi: 10.19045/bspab.2015.44009

Kassam, A., Friedrich, T., Shaxson, F., \& Pretty,J. (2009). The spread of Conservation Agriculture: justification, sustainability and uptake. International Journal of Agricultural Sustainability, 7(4), 292-320. Doi: 10.3763/ ijas.2009.0477

Lal, R. (2004). Carbon emission from farm operations. Environment International, 30(7), 981-990. Doi: 10.1016/j.envint.2004.03.005 
Limon-Ortega, A., Sayre, K. D., Drijber, R. A. \& Francis, G. A. (2002). Soil attributes in a furrow-irrigated, bed planting system in northwest Mexico. Soil E Tillage Research 1635: 1-10. Doi: 10.1016/S01671987(01)00230-6

Nuttall, J. G., Barlow, K. M., Delahunty, A. J., Christy, B. P. \& O’Leary, G. J. (2018). Acute high temperature response in wheat. Agron.J. 110:1296-1308. Doi: 10.2134/agronj2017.07.0392

Ruiz-Corral, J. A., Díaz-Padilla, G., Guzmán-Ruiz, S. D., Medina-García, G., \& Silva-Serna. M. M. (2006). Estadísticas Climatológicas Básicas del Estado de Baja California (Periodo 1961-2003). Instituto Nacional de Investigaciones, Forestales, Agrícolas y Pecuarias. http://www.simarbc.gob.mx/descargas/ estadclimatologica-inifap.pdf

Saifuzzaman, M., Rawson, H. M., Amin, M., Farhad, M., Helal Uddin, M., Sydur Rahman, M., Farhad Hossain M. \& Enamul Haque, M. (2011). Beds or flat-planting for southern wheat crops. Report number: ACIAR Technical Report 78. https://www.researchgate.net/publication/264574527_Beds_or_flatplanting_for_southern_wheat_crops

Salinas-Zavala, C. A, Salvador E, Lluch-Cota, \& Fogel, I. (2006). Historic development of winter-wheat yields in five irrigation districts in the sonora desert, Mexico. Interciencia, 31(4), 254-261. http://ve.scielo.org/ scielo.php?script=sci_arttext\&pid=S0378-18442006000400004\&lng=es\&nrm=iso

SIAP (2014) Servicio de Información Agroalimentaria y Pesquera. Avance de siembras y cosechas. Resumen nacional por cultivo. http://infosiap.siap.gob.mx:8080/agricola_siap_gobmx/AvanceNacionalSinProgramado

Verhulst, N., Sayre, K.D., Vargas, M., Crossa, J., Deckers, J., Raes, D. \& Govaerts, B. (2011). Wheat yield and tillage-straw management system $\mathrm{x}$ year interaction explained by climatic co-variables for an irrigated bed planting systems in northwestern Mexico. Fields Crops Research 124:347-356. Doi: 10.1016.j.fcr.2011.07.002

Verhulst, N., Kienle, F., Sayre, K. D., Deckers, J., \& Raes, D. (2014). Soil quality as affected by tillage-residue management in a wheat-maize irrigated bed planting system. Plant Soil 340, 453-466. Doi: 10.1007/ s11104-010-0618-5

Verhulst, N., François, I. \& Govaerts, B. (2015) Agricultura de conservación, ¿mejora la calidad del suelo a fin de obtener sistemas de producción sustentables?. Centro Internacional de Mejoramiento de Maíz y Trigo. Modernización Sustentable de la Agricultura Tradicional. https://repository.cimmyt.org/bitstream/ handle/10883/4408/56985.pdf? sequence=4\&isAllowed=y

Wuest, S. B., Gaesar-Tonthat, T. C., Wright, S. F., \& Williams, J. D. (2005). Organic matter addition, N, and residue burning effects on infiltration, biological, and physical properties of an intensively tilled siltloam soil. Soil and Tillage Research, 84(2), 154-167. Doi: 10.1016/j.still.2004.11.008

Zuber, S. M., Behnke, G. D., Nafziger, E. D., \& Villamil, M. B. (2015). Crop rotation and tillage effects on soil physical and chemical properties in Illinois. Agronomy Journal, 107(3), 971-978. Doi: 10.2134/ agronj14.0465 